\title{
The Practice of Economic Planning and The Optimum Allocation of Resources: Discussion
}

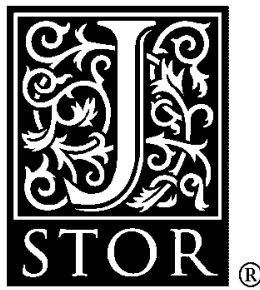

Francois Perroux; J. Tinbergen; Jacques Rueff; Evsey D. Domar; E. F. Lundberg; M. Kalecki; J. Zagorski; K. Dalal

Econometrica, Vol. 17, Supplement: Report of the Washington Meeting. (Jul., 1949), pp. 172-178.

Stable URL:

http://links.jstor.org/sici?sici=0012-9682\%28194907\%2917\%3C172\%3ATPOEPA\%3E2.0.CO\%3B2-S

Econometrica is currently published by The Econometric Society.

Your use of the JSTOR archive indicates your acceptance of JSTOR's Terms and Conditions of Use, available at http://www.jstor.org/about/terms.html. JSTOR's Terms and Conditions of Use provides, in part, that unless you have obtained prior permission, you may not download an entire issue of a journal or multiple copies of articles, and you may use content in the JSTOR archive only for your personal, non-commercial use.

Please contact the publisher regarding any further use of this work. Publisher contact information may be obtained at http://www.jstor.org/journals/econosoc.html.

Each copy of any part of a JSTOR transmission must contain the same copyright notice that appears on the screen or printed page of such transmission.

JSTOR is an independent not-for-profit organization dedicated to and preserving a digital archive of scholarly journals. For more information regarding JSTOR, please contact support@jstor.org. 


\section{Discussion}

\section{Perroux:}

L'intéressante communication d'Ọ. L a $\mathrm{n}$ g e fournit à tous ceux qui ont bénéficié déjà de ses précédents travaux, un motif supplémentaire de reconnaissance. Sa base même, ne peut, cependant, être acceptée par moi.

A-Je note que le théoricien socialiste a complètement changé de méthode. Il a autrefois essayé de montrer qu'une économie socialiste peut fonctionner a peu près comme une économie de marché, sur la base de calculs isolés des unités (règle du coût marginale). Il fonde aujourd'hui sa thèse sur les macrodécisions de l'Etat. Il le fait paradoxalement au moment précisément où tout le monde est d'accord sur la necessité $\mathrm{du}$ breakdown of the aggregate quantities.

B-Notre problème est: Comment l'Etat peut-il former des macrodécisions économiques rationnelles? Cela suppose que la Centrale collectiviste ne décide pas', préalablement, que ses choix coïncident nécessairement avec ceux des individus et ne se réfugie pas dans le démarquage de la politique même usitée par le capitalisme auquel elle succède.

C-O. Lange n'a pas discuté la rationalité économique des macrodécisions. Aucune des méthodes auxquelles on peut penser n'est praticable. Ni le calcul des effets objectivement utiles (rations "normales" en termes de laboratoire). Ni le calcul des surplus du producteur et du consommateur. Ni le calcul des maxima (exemple: la consommation qui maximise l'investissement). La théorie des macrodécisions reste à faire. Les plans collectivistes qui ont été concrètement élaborés et mis en oeuvre sont empiriques au sens le moins défendable de ce mot.

D-La distinction de la période de reconstruction et de la période d'expansion suggérée par 0 . Lange me semble illégitime. Il n'y a aucune raison, tout au contraire, de reproduire dans un plan collectiviste de 1947, la structure passée d'une économie de marché en 1938. Tout plan est une tension entre le passé et le futur. Si le socialisme répète les leçons de l'économie qu'il prétend remplacer, il avoue son impuis, sance.

E-La Théorie Economique s'est appliquée à des calculs économiques isolés et marginaux. Elle ne nous a presque rien dit sur un autre type de calculs économiques: les calculs globaux qui impliquent des paris sur l'opportunité des structures neuves. Si le socialisme théorique a quelques services à nous rendre, c'est en élaborant cette dernière. théorie: je ne la trouve pas dans l'exposé de 0 . Lange. 


\section{Mr. Tinbergen:}

I have been struck by the fact that there is much similarity between the way in which Dr. L a $\mathrm{n}$ g e puts his problems and the way in which we are accustomed to put our problems in some Western European countries. The planning in the Netherlands, which I may perhaps choose as an example, is rather detailed for the moment, in view of the extreme scarcity of foreign exchange and of other factors of production. It might be that in later years the planning would take the shape of a more over-all character.

But for the moment, as I said, there is a great similarity. And I quite agree with Dr. Lange that it is hardly possible to take decisions only on a rational basis. I should like to add, however, that in free economies also, there are a number of important decisions that are not rational, either. It seemed nevertheless possible, in some cases, somewhat to rationalize decisions.

The first example concerns investments. These were provisionally estimated on the basis of the total number of workers for whom employment has to be provided in the next five years and the average capital per worker that is customary in the Netherlands.

As a further example, I may perhaps add the example on the plan for building schools which was based on forecasts of the number of children to be expected and the need for trained workers.

Another example is in a similar program for hospitals.

It was possible to some extent to give a background to the rationing system of the government, by comparing rations to the budget statistics of prewar times, taking account of a number of corrections.

Dr. Lange also invited us to answer the question whether it would be possible to test the efficiency of this type of semi-planned economies. It is very difficult indeed, as you can surmise, to make such a test. One rather superficial but not uninteresting possibility, however, in the case of the Netherlands, seems to be the comparison with Belgium, a country whose economy is much freer than the Dutch economy is at present. And now it is interesting to state that the velocity with which the general index of production for industry has gone up in both countries since the very low point that was reached in the beginning of 1945 has been almost the same in both countries. Moreover, price control and wage control had far more success in Holland than it had in Belgium.

On the question raised by Dr. Lange, in what respect it would be possible to take more advantage of marginal analysis for advising the government on its economic policy, I should like to answer that, even if we did not succeed in finding very fine instruments of distributing resources, it might be not such a terrible accident for this transitory period 
of great scarcity. Generally speaking, however, I think it is too early yet to answer this question. Therefore, collecting experiences as we are now doing may be useful for all countries involved.

\section{Rueff:}

Je tiens, en premier lieu, à rendre hommage au très remarquable exposé de M. L a $\mathrm{n} g$ e. Je voudrais seulement ajouter une question à celles qui lui ont été posées. Je voudrais qu'il nous indique les méthodes par lesquelles les prévisions du plan peuvent être transformées en réalité.

En effet, en régime planifié, si la conduite des producteurs et des consommateurs n'est pas déterminée par des prix tels qu'ils les incitent à vouloir spontanément accomplir les actes susceptibles de conduire à l'équilibre économique, il faut que ces actes leur soient imposés.

Le drame des politiques planifiées dans beaucoup de pays, c'est, qu'en fait, producteurs et consommateurs restent libres de se décider d'après les prix du marché, alors que ceux-ci ne sont pas ce qu'ils doivent être pour que les prévisions du plan soient satisfaites.

Je voudrais que M. Lange nous dise quelles méthodes pratiques doivent être employées pour que le plan soit, en fait, efficace.

\section{Mr. Domar:}

My remarks are theoretical. Assuming that our objective is to satisfy consumer wants with a minimum of centralized interference, the problem of resource allocation falls into two parts: how to determine the desirable pattern of behavior on the part of industrial managers, and how to make them behave in the desirable manner.

In either society, the first problem is solved in the well-known manner of equating marginal costs to prices. In a capitalist society with perfect competition, the second one is solved by allowing producers to maximize their profits. The emergence of monopoly (in its several manifestations) destroys this solution, and so far no other has really been found.

In a socialist society (according to Lange and Lerner), the second problem is solved by instructing the managers to equate marginal costs to prices. But what incentives will society offer to make them behave in this manner? And what method will be used to determine whether they so behave? Surely we cannot merely rely on their sense of duty. Nor is it practical administrative policy to make a continuous study of their accounting records: all decisions are made for the future, and perfectly honest differences of opinions are possible. I don't believe that either our economic theory or Mr. Lange's paper have answered these questions. 
A similar question arises in connection with uncertainty. We don't want the managers to be foolhardy, nor do we want them never to take chances. So the punishment for a failure must be severe, but not too severe to inhibit experimentation; and the reward for success must be generous, but not too generous to encourage waste. I don't know how the socialist society will solve this dilemma, yet on its proper solution depends its whole economic development and progress.

For the United States these are academic questions. - But they must be real and urgent in Europe, and I would like to ask the speakers whether much thought has been given to them in their respective countries.

\section{Mr. Lundberg:}

There is a fundamental difficulty with regard to effective planning that I think is on our minds, and is implicitly involved in the speeches that we have heard, not least in. Professor $\mathrm{L}$ a $\mathrm{n} g$ e's lecture. But it has to be said explicitly. This difficulty refers to the disturbing fact of politics in a free democracy. The concentration of interest naturally tends towards the questions of income distribution on the cost of positive planning. I like to draw a parallel with the development of planning in Sweden during the postwar years.

One of the main problems with regard to the future development of the Swedish economy refers to the stagnation in population growth. There will hardly be any increase for twenty years in our labor force. That means great difficulty for a capitalist system to work. One of the ways to solve that problem is to get labor from agriculture where there are certain reserves. An agricultural planning commission has been working for four years with thirty members.

The economists in that commission made a dynamic plan for agriculture put into a framework of the general Swedish employment development. The solution implied a continuous rationalization of agriculture during a period of a generation without danger for our food situation. We could calculate the marginal cost of having more of agriculture than according to that plan, that is to say the real price for security in food supply. But when the politicians got hold of the plan their main interest was the equalization of income between agriculture and the other parts of the population. I will by this example only remind you of the risk that politicians in a free society will be much more interested in income distribution than in long-term planning because of the fact that they to a large extent represent different pressure groups. And this of course is very disturbing for long-term planning. My conclusion is that in order not only to have good plans made up by experts in different fields and consistent planning for the economy as a whole but also will and power to make the plans work, we have either to have 
an enlightened dictatorship, if I may say so, or a people very united about the aims of economic policy.

If you have a free society, then you can have people united about the aims of economic policy under the condition that these aims seem predominating to all of us. That was the situation after the war in countries with large rebuilding and reconstruction problems such as Poland and the Netherlands, as Professor T. in b e $\mathrm{r}$ g e $\mathrm{n}$ said. Then you can get a general understanding of and common interest in the plans. In Sweden the needs have not been urgent to the same extent and therefore we get too much of the income-(and power-) distribution problems about which people cannot easily agree with much room for politicians to play in. However, the Swedish economic policy has not been able to save Sweden from the dollar crisis (partly just because of its emphasis on the income-distribution aspects). Although we may regret it the new alarming difficulties, breeding urgent needs, will perhaps make better prospects for efficient planning in the future.

\section{Mr. Kalecki:}

I think that the basic mistake in this discussion is to compare what actually exists to something that has never existed. The present planned or controlled economies are being compared to capitalist economy as it was pictured in textbooks until recent times, where it was endowed with perfect equalization of marginal cost and prices, small degree of unemployment, optimum distribution of resources, and so on and so forth. In fact, it was an apologistic myth of the capitalist economy and nothing of the sort has ever existed. Frices were never equal to marginal cost; unemployment was considerable, and so on. It is from this point of view that the problems of the present discussion should be considered.

Take for instance the problem of the slow response to changes in the pattern of demand in a fully employed economy. It is true that in a normal capitalist economy this response is very quick; but this is due to the fact that usually a significant part of productive equipment and of available labor is unemployed.

Another problem considered in the present discussion was whether it would be possible in a planned economy to achieve equalization between prices and marginal cost. However, it is perfectly clear that in a capitalist economy prices are really not determined that way but by average prime cost and something like the degree of monopoly or by "full cost" principle. Does this assure the optimum distribution of resources? Why should we then complain that under planning or controls there is no exact equalization between prices and marginal cost if this has never been realized? 
I should like still to add a word about devastated countries. In consideration of planned and controlled economies in devastated countries, you have to compare them with what would actually have happened if their economies should be "free". An extreme shift to profits from other incomes would take place in present circumstances and the demand for luxury goods would influence to a great extent the pattern of production. Now, however great are the difficulties of planning production in Eastern Europe, I still prefer the priorities established by it to those determined by the demand of black marketeers.

\section{Mr. Zagorski:}

The present state of economic planning in Poland, because of the enormo us destruction has certain special characteristics. When Professor $\mathrm{L}$ a $\mathrm{ng}$ e said that we are in the stage of reconstruction, he did not mean what Professor Perroux tried to suggest, that our aim.is to reconstruct all that was before, for it is not. Every decision as to reconstruction is before examiners who know of the changed economic conditions. What Professor Lange had in mind is this, that Poland is in this stage of intra-marginal decision which means every decision is a right one; when the time comes for extra-marginal decisions, and I hope it will be very soon, I hope that our distinguished counsellor will come back to our country and help us to get a most efficient and most rationalized and optimum economy. For such is, in my opinion, the intention of the Polish Government. However, in my personal opinion, I don't think that conditions of the optimum system elaborated by Professor L e r n e r and Professor Lange are practicable or are just. I don't think you can gather individual cost aggregates into social marginal costs, and I think it is social marginal costs that must be taken into consideration when you try to construct an optimum system.

As to the question whether we shall ever get an optimum system, or whether we shall get an efficient system, of course it is very difficult to answer. We can answer only in a comparative way. It is certain, to me at least, that you cannot get an optimum system in a capitalist economy. In order to get an optimum system in a capitalist economy, you must abolish monopoly profits, and abolishing monopoly profits means, of course, abolishing capitalism. In our country, as far as I understand it, the chief principle is to equate prices to average cost. There are no monopoly profits in Poland worth mentioning, at least in the nationalized sector. And I think, whatever be the ultimate conditions for optimum systems, this principle will get us nearer an optimum system than the capitalist countries. 


\section{Mr. Dalal:}

The system of prices fixed freely in the markets to equate supply and demand performs, among other functions, that of shifting resources from the uses where they are less urgent to uses where they are more urgent, as reflected in the relative price of the different uses of the limited resources. This function of the price system can be called the dynamic function of prices.

In devastated economies or economies that are fundamentally disequilibriated, the price system fails to perform the dynamic function. It is often observed that even if the prices offered for the particular uses of resources rise, those resources fail to be augmented. The productive or distributive system ceases to be sensitive enough to the changes in prices. Under these circumstances, when the price system no longer performs its dynamic function, there is a logical and economic basis for controls and planning to achieve an optimum allocation of resources. 